\section{Acute pulmonary oedema}

Aust Prescr 2017:40:126

https://doi.org/10.18773/austprescr.2017.051

After reading the article on managing acute pulmonary oedema, ${ }^{1}$ I would like to point out the following. Pulmonary embolus causes pulmonary ischaemia not oedema. Nitrates do not cause coronary vasodilatation as they are already maximally dilated by way of autoregulation. Morphine causes coronary vasoconstriction in conscious dogs. ${ }^{2}$

\section{Robert McRitchie}

\section{Flinders Medical Centre}

Adelaide

\section{REFERENCES}

1. Purvey M, Allen G. Managing acute pulmonary oedema. Aust Prescr 2017;40:59-63. https://doi.org/10.18773/ austprescr.2017.013

2. Vatner SF, Marsh JD, Swain JA. Effects of morphine on coronary and left ventricular dynamics in conscious dogs. J Clin Invest 1975;55:207-17. https://doi.org/10.1172/ JCl107923

Megan Purvey and George Allen, the authors of the article, comment:

We have further reviewed the literature and agree that pulmonary embolus does cause regional ischaemia, but it is also listed as a precipitant of acute heart failure in the 2016 European Society of Cardiology Guidelines for the Diagnosis and Treatment of Acute and Chronic Heart Failure.' Similarly, we were guided by the 2005 version of these guidelines which, when discussing nitrates, stated 'At low doses they only induce venodilation, but as the dose is gradually increased they cause the arteries, including the coronary arteries, to dilate'?

We appreciate your clarification of morphineinduced coronary vasoconstriction ${ }^{3}$ as a mechanism of why morphine may cause harm if used in acute pulmonary oedema.

\section{REFERENCES}

1. Ponikowski P, Voors AA, Anker SD, Bueno H, Cleland JG, Coats AJ, et al. 2016 ESC Guidelines for the diagnosis and treatment of acute and chronic heart failure: the Task Force for the diagnosis and treatment of acute and chronic heart failure of the European Society of Cardiology (ESC). Developed with the special contribution of the Heart Failure Association (HFA) of the ESC. Eur Heart J 2016;37:2129-200. https://doi.org/ 10.1002/ejhf.592

2. Nieminen MS, Böhm M, Cowie MR, Drexler H. Filippatos GS, Jondeau G, et al.; ESC Committee for Practice Guidelines (CPG). Executive summary of the guidelines on the diagnosis and treatment of acute heart failure: the Task Force on Acute Heart Failure of the European Society of Cardiology. Eur Heart $J$ 2005;26:384-416. https://doi.org/10.1093/eurheartj/ ehi044

3. Vatner SF, Marsh JD, Swain JA. Effects of morphine on coronary and left ventricular dynamics in conscious dogs. J Clin Invest 1975:55:207-17. https://doi.org/10.1172/ JCl107923 